\section{What is IUGS}

The International Union of Geological Sciences (IUGS) is one of the largest and most active non-governmental scientific organizations in the world. Founded in 1961, IUGS is a member of the International Council of Scientific Unions. IUGS promotes and encourages the study of geological problems, especially those of worldwide significance, and supports and facilitates international and interdisciplinary cooperation in the earth sciences.

At present IUGS gives special consideration to:

- initiatives related to the identification and assessment of energy and mineral resources;

- global change;

- geologic hazards; and

- environmental geology

IUGS Commissions, Committees, and Boards are concerned with a wide range of geologic research of direct interest to governments, industry, and academic groups within the earth sciences. IUGS believes that it is of mutual benefit to establish close links with other organizations engaged in geoscience activities, and especially those organizations whose work relates to some of the major activities of IUGS.

\section{How did IUGS originate?}

The Union was founded in March of 1961 in response to a need to coordinate geoscientific international research programs on a continuing basis. Geoscientists felt that a mechanism was required to take action on global geological problems between the International Geological Congresses, traditionally held every four years.

IUGS was also to serve as a vital link in solving problems requiring interdisciplinary input from other international scientific unions operating under the aegis of the International Council of Scientific Unions. Compared to these, IUGS was a "latecomer," although some of its responsibilities had been carried out by the International Geological Congress a venerable institution over a century old.

Since 1961, IUGS has experienced rapid growth in membership, scientific scope and expertise, as well as international prestige.

\section{What does IUGS do?}

IUGS fosters dialogue and communication among the various specialists in earth sciences around the world. It achieves this by organizing international projects and meetings, sponsoring symposia and scientific field trips, and producing publications. Topics addressed span the gamut from fundamental research to its economic and industrial applications, from scientific, environmental and social issues to educational and developmental problems. For example,

IUGS is currently involved in:

- identifying and defining the problems critical to an improved understanding of terrestrial and planetary geological processes; encouraging formulation and testing of new geological concepts, models, and methodologies;

- focusing effort internationally on the study of critical economic or environmental problems whose resolution may depend on an understanding of geology;

- fostering international agreement on nomenclature and classification in several geoscientific disciplines such as stratigraphy, petrology and tectonics;

- strengthening mechanisms for facilitating international cooperation in geological research and exchange;

- improving publication, dissemination, and use of geological information internationally;

- encouraging new relationships between and among disciplines of science that relate to geology worldwide;

- attracting competent students and research workers who will devote their attention to geology, and to stimulate excellent education for students interested in geology;

- fostering an increased awareness among individual scientists world-wide of what programs are being carried out in geology in each country;

- promoting public understanding and appreciation of the planet earth, its environment in space, and their study; and

- furthering the public welfare by assuring that geology makes appropriate contribution to public policy decisions of an international nature.

\section{IUGS Scientific Work}

\section{Commissions}

The Union has several standing Commissions dedicated to studying a particular geological field, methodology or problem. At present, IUGS Commissions include the:

- Commission on Comparative Planetology

- Commission on Igneous and Metamorphic Petrogenesis

- Commission on the Management and Application of Geoscience Information

- Commission on Global Sedimentary Geology

- Commission on the History of Geological Sciences

- Commission on Stratigraphy

- Commission on Systematics in Petrology

- Commission on Tectonics

- Commission on Fossil Fuels

- Commission on Geology for Environmental Planning

Commissions vary in size; each is composed of a suitable number of geographically representative experts. They are often sub-divided into Subcommissions, Regional Committees or Working Groups according to the specific tasks charged to them.

\section{Committees}

Committees, task groups or working groups carry out short-term or temporary assignments, often to determine the extent of IUGS effort required in areas not covered by Commissions or associations affiliated to IUGS. Current committces include the Committee on Statutes and Bye-laws and the Nominating Committee.

\section{Advisory Boards}

In providing expert advice to the Executive Committee, Advisory Boards convene meetings, conduct reviews, and prepare reports and recommendations, generally on an annual basis. Advisory Boards and their members serve under specified terms of reference and for specified times. The Advisory Board for Research Development is a group of widely recognized scientific experts and successful managers of major scientific programs in industry, and in governmental or academic sectors. This Board recommends re-direction of effort in programs or projects, initiation of new activities, or formulation of future research themes to assist in longer term program planning. When appropriate, the Board also makes recommendations on overall science management issues, and on funding levels necessary to support IUGS projects. The Advisory Board for Publications provides recommendations on a series of issues concerning IUGS publishing activities.

\section{Executive Committee}

\author{
President \\ Dr. Robin Brett \\ U.S. Geological Survey \\ 917 National Center \\ Reston, VA 22192 \\ USA \\ Tel: +17036486164 \\ Telex: 248418 GEOINT UR \\ Fax: +17036484227 \\ E-mail: rbrett@usgs.gov
}

\section{Secretary General}

Dr. Attilio C. Boriani

Dipartimento di Scienze della Terra

Universit degli Studi di Milano

Via Botticelli 23

I-20133 Milan

ITALY

Tel: +39223698310

Fax: +39270638681

Telex: UNIMI 320484

E-mail: Boriani@R10.TERRA.UNIMI.IT

\section{Treasurer}

Dr. Zdenek Johan

Bureau des Recherches Géologiques et

Miniéres (BRGM)

B.P. 6009

F-45060 Orleans Cedex 2

FRANCE

Tel: +33.382643701

Fax: +33382643990

E-mail: iugs@brgm.fr 


\section{Past President}

Prof. William S. Fyfe

Department of Earth Sciences

$B$ and $G$ Building

University of Western Ontario

London, Ontario

CANADA N6A $5 B 7$

Tel: +1 5196613180

Fax: +15196612179

E-mail: mmcmahon@julian.uwo.ca

\section{Vice President}

Dr. Wissam S. Al-Hashimi

Arab Geologists Association

P.O. Box 1247, code 12112

Baghdad

IRAQ

Tel: +964 I 5561205

Fax: +96417193532

\section{Vice President}

Dr. Gabor Gaál

Hungarian Geological Survey

Stefánia út 14

P.O. Box 106

H-1442 Budapest

HUNGARY

Tel: +3612514680

Fax: +3612510703

\section{Vice President}

Prof. Francisco Hervé

Dept. of Geology and Geophysics

Universidad de Chile

Casilla 13518 Correo 21

Santiago

CHILE

Tel: +56 26982071

Fax: +5626963050

E-mail: fherve@tamarugo.cec.uchile.cl
Vice President

Liu Dun-yi

Institute of Geology C.A.G.S.

Chinese Academy of Geological Scienc

Baiwanzhuang Road 26, Fuchengmenwai

Beijing 100037

CHINA

Tel: +861068311545

Fax: +861068311545

\section{Vice President}

Prof. Isaac O. Nyambok

University of Nairobi

College of Biological \& Physical Science

Department of Geology

P.O. Box 30197

Nairobi

KENYA

Tel: +2542449233

Fax: +2542449539

E-mail: uonseism@avcc.or.ke

\section{Vice President}

\section{Dr. Ian G. Speden}

Institute of Geological and Nuclear Sci-

ences

P.O. Box 30-368

Lower Hutt

NEW ZEALAND

Tel: +64 45701444

Fax: +6445690600

E-mail: i.speden@gns.cri.nz

\section{Vice President}

Prof. Vilen A. Zharikov

Dept. of Geology, Geophysics, \& Geochemistry

Russian Academy of Sciences

Lenin Prospect 32a

Moscow 117334

Russia

Tel: +70959380940

Fax: +70959381844

E-mail: zharikov@lem.sherna.msk.su

\author{
Secretariat \\ Hanne Refsdal \\ Geological Survey of Norway \\ Leiv Erikssons vei 39 \\ P.O. Box 3006 - Lade \\ N-7002 Trondheim \\ NORWAY \\ Tel: +4773904166 \\ Telex: 55417 NGU N \\ Fax: +4773921620 \\ E-mail: Hanne.Refsdal@ngu.no
}

\section{Episodes}

(IUGS Quarterly Newsmagazine)

\section{Editor}

Prof. Zhang Hongren

P.O. Box 823

26 Baiwanzhuang Road

100037 Beijing

CHINA

Tel: +861068320827

Tel: +861068327772

Fax: +861068328928

E-mail: episodes@public.east.cn.net

E-mail: igcbj@public3.bta.net.cn

\section{World Wide Web}

\author{
Webmaster \\ Dr. John M. Aaron \\ 2504 Charlestown Lane \\ Reston, VA 20191 \\ USA \\ Tel: +17038600092 \\ Fax: +17036201760 \\ E-mail: jaaron@his.co
}

\title{
Episodes CALLS FOR PAPERS
}

Episodes is the quarterly science and news journal of the International Union of Geological Sciences (IUGS). It focuses on the publication of results of scientific research and other information addressing issues of interest to the global earth-science community. Special emphasis is given to topics involving geological aspects of population growth and economic development and their resulting impacts on or implications for society. As the principal publication of the IUGS, Episodes also carries information about IUGS scientific programs and activities to the extent necessary to communicate effectively with the worldwide IUGS constituency.

Contributions of the following types of manuscripts are here solicited:

- scientific articles

- conference reports

- news and views

- letters to editor

- book reviews

- information on training courses (especially those geared to participants from developing countries)

- noteworthy new publications, including national or regional geologic maps

Episodes also invites photos or other images for the front cover. Photos must be of high technical quality and tell an interesting geological story. A color transparency and one color print (at least $9 \mathrm{~cm} \times 12.6 \mathrm{~cm}$ ) are required for submission, which should be supplemented with a short explanatory paragraph (no more than 100 words).

Please address all contributions to:

\author{
The Editor \\ Episodes \\ P. O. Box 823, 26 Baiwanzhuang Road \\ 100037 Beijing, CHINA \\ Tel: +86-10-68320827; Fax: +86-10-68328928; E-mail: Episodes@public.east.cn.net
}

